\title{
Efektivitas Penggunaan Media Interaktif Berbasis ICT terhadap Hasil Belajar IPS Terpadu
}

\author{
Oleh: Tri Worosetyaningsih \\ Guru SMP N 2 Ngemplak Sleman
}

\section{Pendahuluan}

Mata pelajaran IPS sebagai bagian integral dari kurikulum sekolah, memerlukan guruguru yang mampu melaksanakan pembelajaran yang efektif, dalam arti menguasai materi, mampu memilih permasalahan yang layak diangkat sebagai bahan belajar, serta mengembangkan strategi pembelajaran yang mampu mengoptimalkan pencapaian kompetensi (Mukminan, 2009: 4). Agar dapat melaksanakan pembelajaran secara efektif diperlukan suatu media pembelajaran, salah satunya dengan penggunaan media berbasis ICT.

Penggunaan media dalam suatu kegiatan pembelajaran merupakan suatu keharusan. Ketika seorang guru mengajar di dalam kelas (class room teaching), penggunaan media pembelajaran yang tepat dapat membantu peserta didik untuk memahami materi pelajaran. Berbagai materi pelajaran yang tidak biasa dilihat secara langsung maka media pembelajaran dapat berfungsi sebagai model suatu obyek. Selain itu penggunaan media dalam pembelajaran juga dapat mempengaruhi efektivitas pembelajaran dalam kelas yang akan berdampak pada peningkatan hasil belajar.

Media memiliki andil untuk menjelaskan hal-hal yang abstrak dan menunjukkan hal-hal yang tersembunyi. Ketidakjelasan atau kerumitan bahan ajar dapat dibantu dengan menghadirkan media sebagai perantara. Bahkan dalam hal-hal tertentu media dapat mewakili kekurangan guru dalam mengkomunikasikan materi pelajaran, tetapi penggunaannya sejalan dengan esensi tujuan pengajaran yang telah dirumuskan (Pupuh, 2007: 65).

Perkembangan teknologi yang sangat pesat telah membawa perubahan besar pada segala bidang, termasuk bidang pendidikan. Dalam pembelajaran teknologi yang dimaksud adalah 
Instruktional Commucation Technology (ICT). Apabila dimanfaatkan dengan tepat, maka ICT dapat meningkatkan mutu pendidikan. Kemajuan teknologi ICT sangat membantu menyeimbangkan peran otak kiri dan otak kanan dalam proses pembelajaran. Proses pembelajaran menjadi semakin interaktif karena ICT mampu menghasilkan bahan ajar yang up to date, metode yang menarik dan media yang relevan. Konsep interaktif dalam pembelajaran paling erat kaitannya dengan media berbasis computer (AzharArsyad, 2010: 100).

Pada kurikulum terbaru SMP/MTs mata pelajaran IPS disusun secara sistematis, komprehensif, dan terpadu dalam proses pembelajarannya. Dengan pembelajaran secara terpadu, diharapkan pembelajaran IPS menjadi lebih bermakna bagi peserta didik dalam konteks kehidupan sehari-hari. Peserta didik akan memperoleh pemahaman yang lebih luas dan utuh. Mata pelajaran IPS mengkaji berbagai aspek kehidupan masyarakat secara terpadu, karena kehidupan masyarakat sebenarnya merupakan sebuah sistem dan totalitas dari berbagai aspek. Kehidupan bermasyarakat bersifat multidimensional, sehingga pembelajaran IPS yang dilaksanakan secara terpadu diharapkan mampu mengantarkan dan mengembangkan kompetensi peserta didik kearah kehidupan bermasyarakat dengan baik dan fungsional, memiliki kepekaan sosial dan mampu berpartisipasi dalam mengatasi masalah-masalah sosial yang terjadi (Depdiknas, 2006: 4).

Namun demikian, pelaksanaannya di sekolah SMP/MTs pembelajaran IPS sebagian besar masih dilaksanakan secara terpisah. Pencapaian Standar Kompetensi dan Kompetensi Dasar mata pelajaran IPS masih dilakukan sesuai dengan bidang kajian masing-masing (sosiologi, sejarah, geografi, ekonomi) tanpa ada keterpaduan di dalamnya. Hal ini tentu saja menghambat ketercapaian tujuan mata pelajaran IPS itu sendiri yang dirumuskan atas dasar realitas dan fenomena sosial yang mewujudkan satu pendekatan interdisipliner dari 
aspek dan cabang-cabang ilmu sosial (sosiologi, sejarah, geografi, ekonomi, politik, hukum, budaya).

Adanya permasalahan dalam meningkatkan kualitas pembelajaran IPS, maka tulisan ini bermaksud untuk menyumbangkan ide bagi pemanfaatan media interaktif berbasis ICT dalam mata pelajaran IPS terpadu terutama bagi peserta didik SMP, sehingga efektivitas pembelajaran akan tercapai dan berpengaruh terhadap hasil belajar.

\section{Efektivitas Media Interaktif Berbasis ICT dalam IPS Terpadu}

Di masa yang akan datang peserta didik akan menghadapi tantangan berat karena kehidupan masyarakat global selalu mengalami perubahan setiap saat. Oleh karena itu, mata pelajaran IPS dirancang untuk mengembangkan pengetahuan, pemahaman, dan kemampuan analisis terhadap kondisi sosial masyarakat dalam memasuki kehidupan bermasyarakat yang dinamis. Mata pelajaran IPS disusun secara sistematis, komprehensif, dan terpadu dalam proses pembelajaran menuju kedewasaan dan keberhasilan dalam kehidupan di masyarakat. Dengan pendekatan tersebut diharapkan peserta didik akan memperoleh pemahaman yang lebih luas dan mendalam pada bidang ilmu yang berkaitan (Permendiknas, 2006: 416).

Kegiatan pembelajaran pada dasarnya merupakan kegiatan interaksi antara peserta didik dan guru. Interaksi yang dibangun dalam kegiatan ini adalah interaksi yang bersifat dua arah dan menempatkan peserta didik sebagai subjek belajar. Kedudukan peserta didik sebagai subjek belajar berarti peserta didik merupakan individu yang aktif, bukan yang pasif, yang hanya menerima apa yang diberikan oleh guru. Dalam model pembelajaran ini peserta didik dituntut untuk banyak melakukan aktivitas sesuai dengan tema yang dikembangkan dalam materi pembelajaran. Peserta didik dituntut untuk menemukan konsep-konsep penting yang dikembangkan dalam tema materi pembelajaran atau melakukan inquiri. Guru berperan 
sebagai fasilitator untuk mengantarkan peserta didik hingga menemukan konsep-konsep tersebut.

Efektivitas penggunaan media pembelajaran sangat tergantung pada derajat kesesuaiannya dengan materi yang akan diajarkan. Disamping itu tergantung juga pada keahlian guru dalam menggunakan media tersebut. Dalam hal ini Dick \& Carey (dalam Lamudji, 2005: 35) menyatakan bahwa salah satu keputusan yang paling penting dalam merancang pembelajaran ialah dengan menggunakan media yang sesuai dalam rangka penyampaian pesan-pesan pembelajaran. Jadi media yang dirancang dapat merangsang timbulnya semacam dialog internal dalam diri peserta didik yang belajar. Dengan perkataan lain terjadi komunikasi antara peserta didik dengan media atau secara tidak langsung antara peserta didik dengan sumber pesan atau guru. Media berhasil membawakan pesan belajar bila kemudian terjadi perubahan kualitas dalam diri peserta didik.

Mengingat SK dan KD cukup banyak dan beragam pembelajaran IPS maka perlu efektivitas yang tinggi dikarenakan materi yang sangat banyak. Untuk itu pembelajaran dilaksanakan secara terpadu agar lebih efektif. Efektivitas berarti berusaha untuk dapat mencapai sasaran yang telah ditetapkan sesuai dengan kebutuhan yang diperlukan, sesuai pula dengan rencana, baik dalam penggunaan data, sarana, maupun waktunya atau berusaha melalui aktivitas tertentu baik secara fisik maupun non fisik untuk memperoleh hasil yang maksimal baik secara kuantitatif maupun kualitatif (Said, 1981: 83 dalam http://ahmadmuhli.wordpress.com).

Untuk dapat memperoleh hasil yang maksimal dalam proses pembelajaran IPS dilaksanakan secara terpadu dengan menggunakan media, yang berfungsi untuk memperjelas maksud dari suatu yang dibicarakan. Dalam pembelajaran sering terjadi salah komunikasi yang disebabkan materi yang terlalu abstrak. Untuk mengurangi tingkat kesalahan komunikasi maka digunakan media belajar/ alat peraga. Alat peraga dalam mengajar 
memegang peranan penting sebagai alat bantu untuk menciptakan proses belajar mengajar yang efektif. Metode dan alat peraga merupakan unsur yang tidak bisa dilepaskan dari unsur lainnya yang berfungsi sebagai cara atau teknik untuk mengantarkan bahan pelajaran agar sampai kepada tujuan (Nana Sudjana, 1989: 99).

\section{Pengaruh Efektivitas Media Interaktif Berbasis ICT Terhadap Hasil Belajar}

Penilaian hasil belajar merupakan aktivitas yang sangat penting dalam proses pendidikan. Semua proses di lembaga pendidikan formal pada akhirnya akan bermuara pada hasil belajar yang diwujudkan secara kuantitatif berupa nilai. Menurut Surya Dharma (2008: 4), hasil belajar merupakan perubahan tingkah laku sebagai akibat dari proses belajar. Surya Dharma juga mengatakan bahwa hasil belajar adalah kemampuan aktual yang diukur secara langsung. Hasil pengukuran belajar inilah akhirnya akan mengetahui seberapa jauh tujuan pendidikan dan pengajaran yang telah dicapai. Oleh karenanya hasil belajar sebagai perubahan tingkah laku meliputi domain/ranah kognitif, afektif, dan psikomotorik.

Hasil belajar siswa tidak selalu mudah untuk dinilai. Sebagaimana diketahui, tujuan pembelajaran meliputi ranah kognitif, afektif, dan psikomotor. Dalam proses penilaian hasil belajar langkah yang pertama harus dimulai dari perumusan tujuan pembelajaran yang memungkinkan untuk diamati dan diukur (observable and measurable). Berangkat dari tujuan pembelajaran yang dirumuskan, maka disusunlah instrumen untuk mengamati dan mengukur hasil pembelajaran (Surya Dharma, 2008: 5)

Salah satu faktor yang ada di luar individu yang mempengaruhi hasil belajar adalah tersedianya media pembelajaran yang memberi kemudahan bagi individu untuk mempelajari materi pembelajaran, sehingga menghasilkan belajar yang lebih baik. Penggunaan media pembelajaran yang efektif akan berpengaruh terhadap hasil belajar. Kemajuan di bidang teknologi pendidikan (educational technology) maupun teknologi pembelajaran (instrutional 
technology) menuntut guru untuk menggunakan media ICT yang lebih maju dalam pembelajaran. Media ICT yang digunakan agar memperoleh hasil maksimal hendaknya dibuat secara interaktif sehingga pembelajaran menjadi lebih bermakna dan melatih kemandirian peserta didik.

\section{Contoh Penerapan Media Interaktif di Sekolah}

Penelitian tentang efektivitas penggunaan media interaktif berbasis ICT terhadap hasil belajar IPS Terpadu pernah dilakukan di SMP N 2 Ngemplak yang terdiri dari dua bagian. Pertama, tingkat efektivitas pemanfaatan Media Pembelajarn berbasis ICT dengan menggunakan powerpoint dengan tema “Erupsi Merapi dan Dampaknya " diperoleh dengan memberikan angket kepada peserta didik. Dari angket yang diberikan, diketahui bahwa sebagian besar peserta didik sangat setuju apabila dalam pembelajaran IPS terpadu menggunakan media pembelajaran berbasis ICT. Kedua hasil/prestasi belajar yang diukur dari nilai pre tes dan pos tes yang dilakukan terjadi peningkatan hasil belajar. Hal tersebut dapat dilihat dari persentase ketuntasan belajar secara klasikal mengalami peningkatan dari sebelum menggunakan media dengan sesudah menggunakan media.

\section{Penutup}

Pembelajaran yang membosan dan media yang ketinggalan jaman sudah tidak menarik bagi peserta didik. Sebagai guru, kami harus mampu mengantar dan memotivasi peserta didik agar memiliki semangat dan hasil belajar yang tinggi. Di era globalisasi saat ini penggunaan ICT sudah tidak asing lagi baik bagi peserta didik maupun bagi guru. Pemanfaatan media berbasis ICT dalam pembelajaran IPS Terpadu sangat diharapkan dalam meningkatkan hasil belajar peserta didik.

Kendala utama dari pembelajaran IPS di sekolah belum melaksanakan pembelajaran secara terpadu dari disiplin ilmu yang ada sehingga materinya sangat banyak dan komplek. 
Untuk mengatasi maka produk media interaktif berbasis ICT untuk mata pelajaran IPS sangat diperlukan. Media sangat di butuhkan dalam rangka pembelajaran yang berbasis PAIKEM. Dengan media pembelajaran interaktif berbasis ICT maka efektivitas pembelajaran akan tercapai dan dapat meningkatkan hasil belajar maka kualitas pendidikan akan lebih tinggi sesuai dengan harapan dari SNP.

\section{Daftar Pustaka}

Azhar Arsyad. 2010. Media Pembelajaran. Jakarta: PT RajaGrafindo Persada. Depdiknas Dirjen Dikdasmen. 2006. Kurikulum 2006 Mata Pelajaran Ilmu Pengetahuan Sosial untuk Sekolah Menengah Pertama(SMP)/Madrasah Tsanawiyah MTs).Jakarta: Direktorat Pendidikan.

Lamudji 2005. Pengaruh Penggunaan OHP terhadap hasil belajar Matematikan pada peserta didik Sekolah Menengah Pertama yang bermotivasi Tinggi dan Rendah. Tesis tidak diterbitkan. Malang: Program Pascasarjana Universitas Negeri Malang.

Mukminan. 2009. IPS dan Cara Pembelajarannya. Yogyakarta: Pascasarjana UNY

Nana Sudjana.1989. Dasar-dasar proses belajar Mengajar.Bandung: Dasar Baru.

Pupuh. 2007. Strategi Belajar mengajar. Bandung: Reifka Aditama

Peraturan Menteri Pendidikan Nasional N0. 22 Tahun 2006 Tentang Standar Isi Pendidikan Nasional.

Surya Dharma, 2008. Penilaian Hasil Belajar. Jakarta: Depdiknas.

http://ahmadmuhli.wordpress.com/2011/08/02/efektivitas-pembelajaran akses pada 29 Juni 2013 jam 20.00 WIB. 